\title{
Achieving Sustainable Supply Chain Performance through Sustainable Production and Sustainable Supplier Management: A Case of Food Manufacturing Sector of Pakistan
}

\author{
Nadir Munir Hassan ${ }^{a}$, Muhammad Nauman Abbasi ${ }^{b}$, Zeeshan Ahmed ${ }^{c}$ \\ ${ }^{a}$ Lecturer, Department of Business Administration, Air University, Multan, Pakistan \\ Email: nadir.magsi@aumc.edu.pk \\ ${ }^{\mathrm{b}}$ Professor, Institute of Management Sciences, Bahauddin Zakaraiya University, Multan, Pakistan \\ Email: abbasimna@bzu.edu.pk \\ ${ }^{c}$ Asst. Prof, Department of Business Administration, Air University, Multan, Pakistan \\ Email: zeeshan.ahmad@aumc.edu.pk
}

\begin{tabular}{|c|c|}
\hline AR' & \multirow{12}{*}{$\begin{array}{l}\text { ABSTRACT } \\
\text { This paper aims to investigate the impact of sustainable practices } \\
\text { especially sustainable production and sustainable supplier management } \\
\text { on supply chain performance. This empirical study demonstrates the } \\
\text { contextual examination of sustainable practices especially with reference } \\
\text { to an emerging economy like Pakistan. Survey was employed to collect } \\
\text { data from } 100 \text { Food Manufacturing Firms. Exploratory Factor Analysis } \\
\text { and Structure Equation Modeling were used through AMOS to test } \\
\text { hypothesis. The results reveal that sustainable production and } \\
\text { sustainable supplier management both significantly impact triple } \\
\text { bottom line. However, sustainable production generate stronger impact } \\
\text { on social performance, while, sustainable supplier management } \\
\text { significantly effects environmental performance. Additionally, the } \\
\text { findings provide valuable insights regarding the use of sustainable } \\
\text { production and sustainable supplier management and their impact on } \\
\text { supply chain performance. Finally, it propagates utility of ecological } \\
\text { value chain management mentioning the impact of couple of sustainable } \\
\text { practices on tipple bottom line. }\end{array}$} \\
\hline His & \\
\hline$A C C$ & \\
\hline$O$ & \\
\hline Key & \\
\hline & \\
\hline Man & \\
\hline retjo & \\
\hline Perfo & \\
\hline JEL & \\
\hline Q01 & \\
\hline 01 & \\
\hline
\end{tabular}

(C) 2020 The authors. Published by SPCRD Global Publishing. This is an open access article under the Creative Commons Attribution-

NonCommercial 4.0

Corresponding author's email address: abbasimna@bzu.edu.pk

\section{Introduction}

There has been an ever rising trend among manufacturing firms to adopt sustainable practices across the globe (Afum et al., 2020). Accordingly, manufacturing organization have developed a reasonable understanding on need for being mindful of environment along with the economics outcomes through use of sustainable supply chain management initiatives (Chin et al., 2015). It is argued that manufacturing sector can play key role in attaining sustainable development either by creating employment opportunities, enhancing societal well-being and/or minimizing environmental 
impact.

In literature, the term "sustainability" has been defined as a corporate responsibility to the individuals of diverse groups, where responsibility states the need to abolish harmful effects of business (Baumgartner, 2014). Likewise, the essence of sustainability need not to be limited within the scope of organizations rather to be extended within and across the supply chains. Sustainable supply chain helps in managing physical resources, fluctuation of information, and fund flows within and across the companies (Seuring \& Müller, 2008) and resultantly help in achieving sustainable goals (i.e. economic, environmental, and social) (Halisçelik \& Soytas, 2019). Along with apparent challenges, sustainable development surely presents certain business opportunities. For example, firms working in an ecological manner, stand a fair chance of improving both status and financial/environmental performance which results in a sustainable competitive advantage (Longoni \& Cagliano, 2015).

Honestly speaking, the significance of sustainability kept on rising since the inception of Sustainable Development Goals. Thenceforth, the United Nations suggest industries to record and share their role and impact on the SDGs (Compact, 2017). A growing percentage of firms are recognizing the significance of environmental sustainability as a business necessities (Blome et al., 2014). Organizations need to be mindful of emerging changes and to be ahead of unique development needs. Further, they need to be responsive and proactively vigilant to both expected and unexpected development needs (Lu et al., 2018).

In prior studies, the focus remained on green practices associated with purchasing and supply chain management (Schmidt et al., 2017), while, it's applicability with respect to social practices (Marshall et al., 2015) remained almost negligible. Earlier studies measured the relationship between sustainable supply chain collaboration with sustainability performance and suggested that future studies must investigate the impact of sustainable supplier management and sustainable production on sustainable performance (Pakdeechoho \& Sukhotu, 2018a). One can find number of such gaps, wherein, similar contexts have been insisted for future investigations. For instance, (Hong et al., 2018) suggested investigation on how buyers exert sustainable practices on a supply chain. Furthermore, Hong et al. (2018) asserted that there is no consensus on how sustainable supply chain management (SSCM) practices can be measured.

In line with the gaps highlighted in the most recent literature, the given study investigates the relationship between sustainable practices i.e. sustainable production \& sustainable supplier management and sustainable performance across the chain. It is believed that the outcomes will assist manufacturing sector especially Pakistani Manufacturing Firms in attaining sustainable performance through sustainable production and supplier management.

\section{Literature Review}

According to Fortune 2020, 94\% of the top 1000 firms, have been exposed to Covid-19 related supply chain hindrances. The pandemic has reshaped the rules of game for almost every walk of life especially manufacturing sector worldwide (Kumar et al., 2020). It is critical to keep an eye on the overall impact of Covid-19 on sustainable production and consumption patterns, as notable variations are likely to emerge over the months and years (Cohen, 2020). Number of research streams have recently been worked on, to counter the adversities of pandemic, with ecological manufacturing seen as one of the emerging remedy (Haleem \& Javaid, 2020). Firms need to be managed in such a manner, which will help reducing the wastes, apparently toxic and hazardous elements, ill-assorted by products, and also aspects which ultimately will help saving energy (Abdul-Rashid et al., 2017). Perhaps, firms 


\section{Review of Economics and Development Studies, Vol. 6 (4) 2020, 941 - 954}

within and across their supply chains have left with no choice except to adopt sustainable practices. Among sustainable practices, supplier selection and sustainable production can generate significant impact on overall supply chain performance.

\subsection{Sustainable Supplier Management (SSM)}

Lately, sustainable practices assumed to be an integral component of the firm's competencies (Pullman, Maloni, \& Carter, 2009). Like many others, sustainable supplier management practices, have also been declared as firm's dynamic capabilities (Dabhilkar et al., 2016). Earlier, supplier selection was limited to the selection of vendor on traditional criteria's like, cost, price, quality, etc. Later on, as the research in the given stream gained importance and became even complicated then the research output became even more sophisticated (Khoshfetrat et al., 2020).

Firms, SSM actions are the product of how they manage to achieve and utilize the concept of sustainability in their procurement across supply chains. The idea of sustainable supplier selection and management is regarded as an acknowledged approach having connections with environmental, economic and social benefits (Khoshfetrat et al., 2020). Tate et al. (2012) pointed out that organization's engagement in environmental actions is on a continuous rise because its helps in both minimizing the cost and increasing the revenue. Comparatively firms utilizing SSM practices are labeled as value oriented and comply by sustainable polices with focus on increasing both ecological and economic positive outcomes (Schaltegger et al., 2014).

In recent times, environmental considerations have gained momentum in procurement and SCM (Galankashi et al., 2015). Studies have shown that choosing suppliers, considering environmental, economic and social priorities leads to attain sustainable development (Büyüközkan \& Çifçi, 2012). So, proper shortlisting of suppliers is critical, as it sets the tone for firm's environmental ambitions (Zhu \& Geng, 2001). Appropriate assessment of suppliers on ecological grounds further guarantees that sustainable actions are in line with firms goals. In comparison to traditional selection process for suppliers, supplier selected using sustainable lens not only considers, their economics achievements, (i.e. after sales services, product quality, transportation and prices etc.), rather also stresses on energy conserving performance, environmental protection and social responsibility (Peng et al., 2020).

Thus appropriate selection of suppliers can help firms in establishing inter firm communication routines, which helps exchange of capabilities, knowledge and resources among channel members. Such collaborative systems possibly helps firms in enhancing ecological effect of their given products and also helps reducing waste across the chain (Klassen \& Vachon, 2003). Additionally, as stated by resource advantage theory, the coordinated relations with suppliers, assist in designing socially acknowledge product, while altering the existing processes in desire of seeking overall operational performances (Pagell et al., 2010). Hence it can be said, that SSM is intended as a high order concept that concurrently deliberates the whole process evaluation of the supply function, selection and collaborative management and helps firms in reaching their sustainable goals.

It is believed that performance of suppliers hold the power of not only affecting manufacturers performance but to influence the performance goals of downstream channel members (Mou et al., 2018). Consequently, it needs to be observed that sustainable supplier selection is a main part of SSCM (Peng et al., 2020). Likewise, Montabon et al. (2016) have propagated to conduct researches even beyond the basic logic of seeking economic performance. Resultantly, considering resource advantage and relational views, SSM surfaces for environmentally conditioned supply wide operation that can eventually confirm lasting competitive advantages to the firms. Therefore we propose that: 


\section{Review of Economics and Development Studies, Vol. 6 (4) 2020, 941 - 954}

$\mathbf{H}_{\mathbf{1}}$ : Sustainable Supplier Management has a significant effect on economic performance. $\mathbf{H}_{\mathbf{2}}$ : Sustainable Supplier Management has a significant effect on environmental performance. $\mathbf{H}_{3}$ : Sustainable Supplier Management has a significant effect on social performance.

\subsection{Sustainable Production (SP)}

The philosophy of green (sustainable) production has its roots since 1990's (Sezen \& Cankaya, 2013), yet it gained major limelight, in couple of recent decades (Rehman et al., 2016). According to US Department of Commerce, sustainable production is an environmental friendly initiative, and defined as "manufacturing the products which ensures the minimization of harmful environmental impacts, preserving energy and natural resource, for consumers and communities, while being economically sound" (Tate et al., 2012). Additionally, Garetti and Taisch (2012) referred sustainable production as a skilled utilization of natural resources across production process, in pursuit of meeting economic, social and environmental requirements. It helps to protect environment and uplift the quality of life. Sustainable production must include diverse elements of sustainability into production activities, like, ecological, financial and societal aspects.

Several initiatives have taken around the globe to lessen the negative impact of production on environment. For this purpose most of such efforts look to reduce unwanted waste, energy consumption, effective use of material and to recover resources (Pajunen et al., 2012). It is a process of aligning firm's processes and systems, with the ability to create quality products, by making use of fewer and ecofriendly resources which are safe for customers, employees and communities around. Further, it may holds the ability to harmonize the socio-environment impacts across its life cycle (Machado et al., 2020).

Similarly, Yoshikawa (2008), states that use of sustainable manufacturing tools not only adds value to firms rather positively effects the overall ecosystem and natural resources. Handfield et al. (2001) mentioned that environmental impact caused by manufacturing, usage and disposal is a byproduct of firm's priorities and choices across the design phase. In simple words, production practices with the aim of sustainable energy utilization through effective management of $\mathrm{CO}_{2}$ emissions, wastes and pollutants will definitely generate a positive impact on ecological performance (Evans et al., 2009).

This study, considers the effect of sustainable manufacturing practices on financial performance (i.e. economics and operational outcomes). While, economic outcomes are the product of productivity, profitability and market share (Rao \& Holt, 2005) and have been operationalized as improved order delivery, improved product quality, reduced cost and flexibility (Vachon \& Klassen, 2006). Similarly, multiple attributes can cause positive sustainable manufacturing strategy, most prominent ones include, developing ecological policies, KPI's, procedures, firms culture, favorable environment and channel members commitment and collaboration for sustainability and technology usage (Bogle, 2017). Further, there is a considerable evidences between sustainable management of value chains, innovation and value creation (Yoshikawa, 2008). Additionally, sound working environment which increases both motivation and productivity, resource efficiency, regulatory compliance, improved firms reputation, better access to market, reduced employee turnover, and causing financial opportunities have also been attributed to sustainable production (Stark et al., 2017). Hence, it is need of the hour that firms must adopt sustainable production practices in order to manage cost and meet the ever rising desire for efficient production process.

From the above discussion we can suggest that: 
Review of Economics and Development Studies, Vol. 6 (4) 2020, 941 - 954

$\mathbf{H}_{4}$ : Sustainable Production has a significant effect on economic performance.

$\mathbf{H}_{5}$ : Sustainable Production has a significant effect on environmental performance.

$\mathbf{H}_{6}$ : Sustainable Production has a significant effect on social performance.

\section{Figure - 1:- Theoretical Framework}

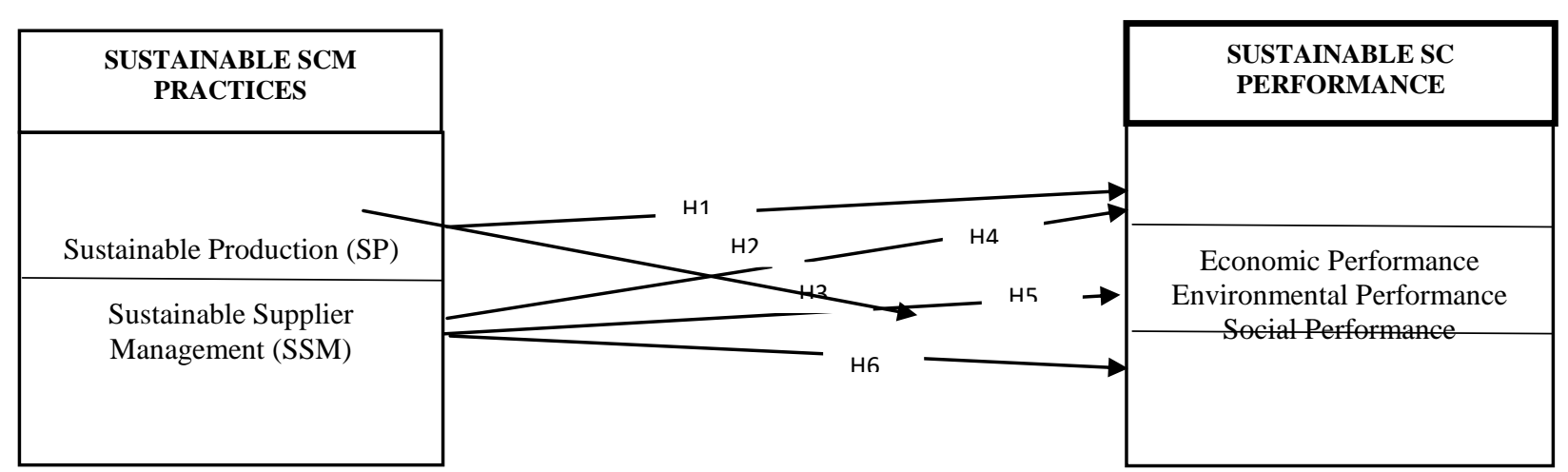

\section{Methodology}

The data was obtained by survey based on the questionnaire. Total 350 companies majorly representing food industry of Pakistan were targeted for data collection. The study consists of large food corporations who could be facing more scrutiny from their multinational consumers, rivals and the federal organizations than smaller companies (Ali et al., 2017). Purposive sampling was used to select appropriate firm and respondent. The data were collected through structured questionnaires, while, managers those who have reasonable knowledge of sustainability and/or representing a department, like, purchase, material management, supply chain, warehousing, production, etc. who are practicing sustainable measures were requested for responses. Three responses from each organization were managed for data validation. After careful screening of 350 responses, 295 (i.e. 84\%) were selected for analysis. 55 responses (i.e. 16\%) were dropped either because of incomplete responses or factual difference were reported within the same organization. The profile of the companies are attached as Annexure - A.

The questionnaire was mainly based on extensive literature review, however, an initial draft were shared with officials working with International Standard of Industrial Classification (ISIC) codes in food industry for their valuable input on each construct. Based on their feedback, necessary amendments were incorporated. The final questionnaire includes questions related to demographic, employees, number of years in the business, items pertaining to sustainability performance, sustainable supply chain practices, performances measures like, outcomes and rewards, etc.

Fifteen items were taken to measure the firm's performance based on three sub-dimensions of sustainability, i.e. economic performance as suggested by (Mitra \& Datta, 2014), environmental performance as used by (Zailani et al., 2012) and the measure for social performance were adapted from (Paulraj, 2011). The respondents were requested to determine their firm's performance on a sevenpoint Likert-type scale, wherein, 1 stands for "Decreased Significantly" and 7 stands for "Increased Significantly". Nine items were adapted from (Veleva \& Ellenbecker, 2001) to determine the extent of sustainable production. Finally, SSM was measured using three dimensions, i.e. supplier selection as suggested by (Min \& Galle, 2001; Zhu \& Geng, 2001; Zhu \& Sarkis, 2004), environmental collaboration as proposed by (Zhu \& Sarkis, 2004), and supplier evaluation as suggested by (Zhu \& Sarkis, 2004). 
Review of Economics and Development Studies, Vol. 6 (4) 2020, 941 - 954

Firm size and major customer types were considered as dummy variables to control the effects on firm's performance such as the customer's where about ( $\mathrm{o}=$ domestic only, $1=$ others) and firm size, considering the number of permanent workers ( $\mathrm{o}=$ less than 200, $1=$ equal to or more than 200).

\section{Analysis and Findings}

The survey results were checked and variance of the models was minimized by using Exploratory Factor Analysis (EFA). Next, Structural equation model (SEM) was applied using AMOS to test the measurement model and the hypotheses.

Cronbach's alpha was applied to test the inner accuracy, while, discriminatory and convergent validity was checked to determine the construct validity of the scale. The values remained appropriate for all constructs. Further, Kaiser-Meyer-Olkin (KMO) results remained higher than the threshold level of 0.7 , thus authenticate the sample size for analysis. Moreover, the results also met the criteria of Bartlett's test of sphericity ( $\mathrm{p}<\mathrm{0.001)}$. The factor loadings of all items on the assigned parameter displayed values above than o.6 (Chin et al., 1997) and the average variance extracted (AVE) values varied between 0.769 to 0.872 and hence accepted as suggested by (Fornell \& Larcker, 1981). Finally, it was evident for the results that all postulated measures unveiled adequate convergent validity.

Table - I: - Constructs, Scale Items and Descriptive Statistics

\begin{tabular}{|c|c|c|c|c|}
\hline Constructs and Scale Items & $\begin{array}{l}\text { Item } \\
\text { Mean } \\
\text { (S.D) }\end{array}$ & $\begin{array}{l}\text { Factor } \\
\text { Loading }\end{array}$ & $\begin{array}{l}\text { Cronbach's } \\
\text { Alpha }\end{array}$ & AVE \\
\hline Sustainable Production (SP) & & & 0.981 & 0.776 \\
\hline $\begin{array}{l}\text { Products and packaging are designed to be safe and } \\
\text { ecologically sound throughout their life cycles; services are } \\
\text { designed to be safe and ecologically sound. }\end{array}$ & 4.85 & 0.878 & & \\
\hline $\begin{array}{l}\text { Wastes and ecologically incompatible byproducts are } \\
\text { continuously reduced, eliminated, or recycled. }\end{array}$ & 4.85 & 0.856 & & \\
\hline $\begin{array}{l}\text { Energy and materials are conserved, and the forms of energy } \\
\text { and materials used are most appropriate for the desired } \\
\text { ends. }\end{array}$ & 4.84 & 0.818 & & \\
\hline $\begin{array}{l}\text { Chemical substances, physical agents, technologies, and } \\
\text { work practices that present hazards to human health or the } \\
\text { environment are continuously reduced or eliminated. }\end{array}$ & $4 \cdot 92$ & 0.823 & & \\
\hline $\begin{array}{l}\text { Workplaces are designed to minimize or eliminate physical, } \\
\text { chemical, biological, and ergonomic hazards. }\end{array}$ & 4.82 & 0.813 & & \\
\hline $\begin{array}{l}\text { Management is committed to an open, participatory process } \\
\text { of continuous evaluation and improvement, focused on the } \\
\text { long-term economic performance of the firm. }\end{array}$ & 4.84 & 0.867 & & \\
\hline $\begin{array}{l}\text { Work is organized to conserve and enhance the efficiency } \\
\text { and creativity of employees. }\end{array}$ & 4.84 & 0.853 & & \\
\hline $\begin{array}{l}\text { The security and well-being of all employees is a priority, as } \\
\text { is the continuous development of their talents and capacities. }\end{array}$ & 4.85 & 0.825 & & \\
\hline $\begin{array}{l}\text { The communities around workplaces are respected and } \\
\text { enhanced economically, socially, culturally and physically; } \\
\text { equity and fairness are promoted. }\end{array}$ & $4 \cdot 92$ & 0.826 & & \\
\hline Sustainable Supplier Selection (SS) & & & 0.959 & 0.826 \\
\hline SS1: We check whether the candidate suppliers meet our & 4.76 & 0.761 & & \\
\hline
\end{tabular}


Review of Economics and Development Studies, Vol. 6 (4) 2020, 941 - 954

predetermined product-based criteria.

SS2: We visit candidate suppliers' factories to assess their facilities and technology levels.

SS3: We check whether the candidate suppliers meet our predetermined environmental criteria.

SS4: We check whether the candidate suppliers meet our predetermined social criteria.

S55: A formal supplier selection evaluation process is performed.

Environmental Collaboration (EC)

EC1: We cooperate with our suppliers to achieve environmental objectives.

EC2: We provide our suppliers with design specification that include environmental requirements for purchased items.

EC3: We encourage our suppliers to develop new source reduction strategies.

EC4: We cooperate with our suppliers to improve their waste reduction initiatives.

EC5: We work with our suppliers for cleaner production.

EC6: We collaborate with our suppliers to provide materials, equipment, parts and/or services that support our environmental goals.

\section{Supplier Evaluation}

SE1: We conduct regular environmental audits into our suppliers' internal.

SE2: We periodically evaluate our suppliers' environmentally friendly practices.

SE3: We make site visits to suppliers' premises to help them improve their eco.

SE4: We encourage our suppliers to get their ISO1400o certification.

\section{Economic Performance}

EN.P1: Decrease in cost of materials purchased.

EN.P2: Decrease in cost of energy consumption.

EN.P3: Decrease in fee for waste discharge.

EN.P4: Improvement in return on investment.

EN.P5: Improvement in earnings per share.

Social Performance

SP1: Improvement in overall stakeholder welfare or betterment.

SP2: Improvement in community health and safety.

SP3: Reduction in environmental impacts and risks to general public.

SP4: Improvement in occupational health and safety of employees.

SP5: Improved awareness and protection of the claims and rights of people in community served.

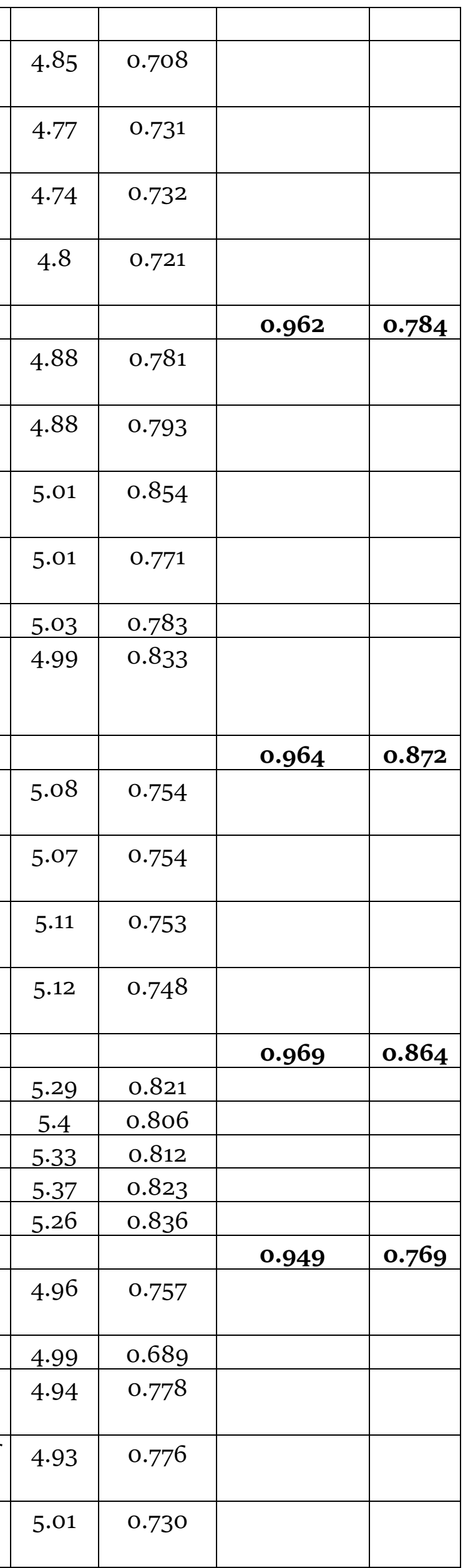


Review of Economics and Development Studies, Vol. 6 (4) 2020, 941 - 954

\begin{tabular}{|l|c|c|c|c|}
\hline Environment Performance & & & $\mathbf{0 . 9 5 5}$ & $\mathbf{0 . 8 0 9}$ \\
\hline EP1: Reduction in air emission. & 5.31 & 0.762 & & \\
\hline EP2: Reduction in waste (water and/or solid). & 5.3 & 0.727 & & \\
\hline $\begin{array}{l}\text { EP3: Decrease in consumption of hazardous/harmful/toxic } \\
\text { materials. }\end{array}$ & 5.35 & 0.759 & & \\
\hline EP4: Decrease in frequency for environmental accidents. & 5.41 & 0.797 & & \\
\hline $\begin{array}{l}\text { EP5: Increase in energy saved due to conservation and } \\
\text { efficiency improvements. }\end{array}$ & 5.35 & 0.779 & & \\
\hline
\end{tabular}

The square root effects of the AVE values were compared with the respective correlation of each item to ensure the discriminant validity of the structures. In Table II, the square roots of AVE surpass the correlation values for each building such that unequal validity is guaranteed (Chin et al., 1997).

Table - II: - Correlations Matrix

\begin{tabular}{|c|c|c|c|c|c|c|c|c|c|c|c|}
\hline & CR & AVE & MSV & $\begin{array}{c}\text { MaxR } \\
\mathbf{( H )}\end{array}$ & $\mathbf{1}$ & $\mathbf{2}$ & $\mathbf{3}$ & $\mathbf{4}$ & $\mathbf{5}$ & $\mathbf{6}$ & $\mathbf{7}$ \\
\hline SP & 0.972 & 0.776 & 0.366 & 0.994 & $\mathbf{0 . 8 8 1}$ & & & & & & \\
\hline EC & 0.956 & 0.784 & 0.384 & 0.987 & $0.463^{* * *}$ & $\mathbf{0 . 8 8 6}$ & & & & & \\
\hline ECP & 0.97 & 0.864 & 0.382 & 0.972 & $0.534^{* * *}$ & $0.513^{* * *}$ & $\mathbf{0 . 9 3}$ & & & & \\
\hline ENP & 0.955 & 0.809 & 0.388 & 0.955 & $0.520^{* * *}$ & $0.619^{* * *}$ & $0.572^{* * *}$ & $\mathbf{0 . 9}$ & & & \\
\hline SP & 0.943 & 0.769 & 0.449 & 0.977 & $0.547^{* * *}$ & $0.552^{* * *}$ & $0.585^{* * *}$ & $0.619^{* * *}$ & $\mathbf{0 . 8 7 7}$ & & \\
\hline SS & 0.96 & 0.826 & 0.534 & 0.961 & $0.605^{* * *}$ & $0.544^{* * *}$ & $0.618^{* * *}$ & $0.623^{* * *}$ & $0.670^{* * *}$ & $\mathbf{0 . 9 0 9}$ & \\
\hline SE & 0.965 & 0.872 & 0.534 & 0.965 & $0.583^{* * *}$ & $0.536^{* * *}$ & $0.602^{* * *}$ & $0.611^{* * *}$ & $0.621^{* * *}$ & $0.73^{* * *}$ & $\mathbf{0 . 9 3 4}$ \\
\hline
\end{tabular}

In our research we opted seven of the model fitness indices (Bagozzi et al., 1991) their corresponding threshold values and observed values have been presented in Table III. The results indicate the good model fitness values for all the statistics.

Table - III: - Goodness-of-Fit Test Statistics

\begin{tabular}{|l|c|c|c|c|c|c|c|}
\hline & $\chi^{2} / \mathbf{d f}$ & RMSEA & GFI & CFI & IFI & TLI & NFI \\
\hline Suggested Values & $<3$ & $<0.08$ & $>0.8$ & $>0.9$ & $>0.9$ & $>0.9$ & $>0.9$ \\
\hline Observed Values & 1.914 & 0.056 & 0.804 & 0.966 & 0.966 & 0.963 & 0.931 \\
\hline Conclusion & Accepted & Accepted & Good fit & Good fit & Good fit & Good fit & Good fit \\
\hline
\end{tabular}

The structural model demonstrates the causal relation between the variables and the calculation of the path coefficients and value of the $\mathrm{R}^{2}$. The $\mathrm{R}^{2}$ value also tests the model's forecast capacity (Hair et al., 2014). The test findings of the hypothesis are summarized in Table IV.

Table - IV: - Structural Model

\begin{tabular}{|c|c|c|c|c|c|c|c|}
\hline \multicolumn{6}{|c|}{ Regression Weights } & \multirow[b]{2}{*}{$\begin{array}{c}\text { P- } \\
\text { value }\end{array}$} & \multirow[b]{2}{*}{ Decision } \\
\hline & & & Estimate & S.E. ${ }^{\mathrm{a}}$ & C.R. ${ }^{b}$ & & \\
\hline $\mathrm{ECP}$ & $<---$ & SP & $0.137^{* * *}$ & 0.068 & 2.43 & 0.015 & Supported \\
\hline SOP & $<---$ & SP & $0.143^{* * *}$ & 0.058 & 2.686 & 0.007 & Supported \\
\hline ENP & $<---$ & SP & $0.114^{* * *}$ & 0.052 & 2.215 & 0.027 & Supported \\
\hline ECP & $<---$ & SSMmean2 & $0.585^{* * *}$ & 0.075 & 10.332 & $* * *$ & Supported \\
\hline SOP & $<---$ & SSMmean2 & $0.625^{* * *}$ & 0.064 & 11.754 & $* * *$ & Supported \\
\hline ENP & $<---$ & SSMmean2 & $0.666^{* * *}$ & 0.057 & 12.904 & $* * *$ & Supported \\
\hline
\end{tabular}

Note: - * $p$-value $\leq 0.1,{ }^{*} p$-value $\leq 0.05,{ }^{* * *} p$-value $\leq 0.001$ 
Review of Economics and Development Studies, Vol. 6 (4) 2020, 941 - 954

${ }^{a}$ S.E. is an estimate of the standard error of the covariance;

${ }^{b} \mathrm{CR}$ is obtained by dividing the covariance estimate by its standard error

The five first order latent variables were used in the framework i.e. (SP, SSM, SP, ECP and ENP), consisting of 50 observable items. Kline (2015) proposed three alternative trajectory parameters $($ Gamma $=\alpha)($ beta $=\beta)$ and $($ Lambda $=\beta)$. The line between DV \& IDV is represented by $(\gamma)$. The lines between all dependent variables are represented by $(\beta)$. The link between the latent variables and the indicators is represented by $(\lambda)$.

Promisingly, the results $(\gamma=.803, \mathrm{p}<0.05) \&(\mathrm{t}=18.928)$ revealed substantial positive relation between ecological/environmental performance and sustainable production. Further, the values $(\gamma=$ $.751, \mathrm{P}<0.05) \&(\mathrm{t}=18.151)$ authenticate considerable positive relationship between sustainable production and social performance. Lastly, the outcomes $(\gamma=.766, \mathrm{P}<0.05) \&(t=20.792)$ exhibit meaningful positive relation between sustainable production and economic performance. From the results, it is can inferred that sustainable production trigger $75.1 \%$ changes in environmental performance, $80.3 \%$ changes in social performance and $76.6 \%$ in economic performance.

Unexpectedly, the results $(\gamma=.127, \mathrm{P}<0.05) \&(\mathrm{t}=3.002)$ demonstrate somewhat weak relationship between sustainable supplier management and environmental performance and it causes only $12.7 \%$ change in environmental performance. In similar manner, the results, $(\gamma=.191, \mathrm{P}<0.05) \&$ $(\mathrm{t}=4.61)$ explain weak, however, positive correlation between sustainable supplier management and social performance. Finally, the values $(\gamma=.194, \mathrm{P}<0.05) \&(t=5.275)$ indicate somewhat positive relationship between sustainable supplier selection and economic performance. Sustainable supplier management can generate $19.1 \%$ difference in social performance and $19.4 \%$ change in economic performance.

\section{Discussion and Conclusion}

The outcomes of this study provide sufficient empirical evidences that sustainable practices in manufacturing can generate notable effects on overall supply chain performance. Results of this study strengthened the existing perceptions regarding sustainable production as a technique to generate environmental positives. Considered the effect of sustainable production practices, on competitive production outputs, it was found, that pollution prevention actions, also cause operational efficiency and reduced production cost.

In the existing literature, (Porter \& Van der Linde, 1995) expressed that environmentally vigilant practices has the potential to generate benefits, which is in line with the outcomes of many studies like, (Ramayah \& Rahbar, 2013) who also stressed that the firms can secure competitive market positions, by making use of sustainable technologies and business practices. Whereas, Ramayah \& Rahbar (2013), observed that there is an identifiable relationship between green manufacturing and production performance (i.e. product quality, cost reduction and delivery performance), which means firms interested in ecological performance, need to adopt sustainable production practices. Similar to outcomes of the above mentioned studies, the given study found that enhanced sustainable performance will not only cause environmental performance, improves the economic feasibility, rather will also be the source of social performance for the manufacturers. This research emphasizes more for sustainable productions and social performance in comparison to ecological and financial performance in context of Pakistan. It also concludes that by adopting strategy, firms cannot only reduces the damages caused through industrial actions rather also helps in sustaining the natural resources from depletion, enhances the quality of life, and protects the future generations from health hazards. 


\section{Review of Economics and Development Studies, Vol. 6 (4) 2020, 941 - 954}

Lastly, results also authenticate that with better sustainable supplier management, organization will end up causing improved sustainable performance, which add to the body of knowledge, as most of the previous studies focused only on ecological and financial dimension of triple bottom line. It also complements the idea that professional and trust worthy buyer-supplier relationship, which is the prime source of information sharing regarding procurement, production and product design etc. helps improving environmental and social aspects of performance, reduces waste, and makes workplace safe and conducive for worker, which complements the findings of the previous studies, that firms sustainable intensity is a product of its suppliers ecology (Krause et al., 2009).

In the end, this study focuses on three aspects of sustainable performance, and results show that SSCMP have more significant impact on social performance, as compared to environmental and financial outcomes. Mainly it reflects that with increase sustainable supplier and production management, there will be a positive increase in firms sustainable, overall performance.

For practitioners, the results of the study are of great importance. Especially in post Covid era, there is an ever increased pressure on firms to adopt sustainable practices, in order to not only reduce financial costs, but also to be socially responsible. As this study reflected an identifiable impact of sustainable practices on sustainable performance, so firms need to adopt these outcomes and must go green and productive. In line with resource based view, sustainable practices serve the role of unique resources, which ultimately prove profitable for firms of present times.

Along with extending the body of knowledge on sustainable practices, through statistical analysis and empirical procedure, this study adds to the scope of prior studies in the field of sustainable supply chain collaboration, within the emerging economies (Pakdeechoho \& Sukhotu, 2018b). Findings might also be of operational guidance for practitioners to enhance their firm's sustainable performance through sustainable SC practices (SP, \& SSM to be specific). Producers in the developing economies might consider and acknowledge the significance of environmental supremacy within firm, which will further uplift the cooperative efforts, and enhances the three dimensional sustainable performance. Finally, this research guides decision makers to provide stakeholders with holistic, transparent and explicit incentives in order to make SSCM and its implementation even viable (Dam \& Petkova, 2014).

Although, the study tried to comprehensively address the issue at hand, still it like other researches isn't free of limitations, some of those may serve the purpose of future directions for upcoming studies. First, future studies may make use of other sustainable supply chain practices, and could measure its impact on overall SCP. Secondly, to further strengthen the proposed hypothesis, future studies may consider some mediating and moderating variables, as in present day's scenario the relation between proposed independent and dependent construct, aren't free of contingent variables and aspects. Likewise, sustainable supply chain integration can be considered as an intervening variable, in the given model, and scholars can take all three dimensions of SSCI in mediating relationship with sustainable supply chain performance. Lastly, to avoid the limitation of generalizability, future aspirants can rely on longitudinal and experimental methodologies to cover up with the issue of time and resources.

\section{References}

Abdul-Rashid, S. H., Sakundarini, N., Raja Ghazilla, R. A., \& Thurasamy, R. (2017). The impact of sustainable manufacturing practices on sustainability performance: empirical evidence from Malaysia. International Journal of Operations \& Production Management, 37(2), 182- 


\section{Review of Economics and Development Studies, Vol. 6 (4) 2020, 941 - 954}

204 .

Afum, E., Osei-Ahenkan, V. Y., Agyabeng-Mensah, Y., Owusu, J. A., Kusi, L. Y., \& Ankomah, J. (2020). Green manufacturing practices and sustainable performance among Ghanaian manufacturing SMEs: The explanatory link of green supply chain integration. Management of Environmental Quality: An International Journal.

Ali, A., Bentley, Y., Cao, G., \& Habib, F. (2017). Green supply chain management-food for thought? International Journal of Logistics Research and Applications, 20(1), 22-38.

Bagozzi, R. P., Yi, Y., \& Phillips, L. W. (1991). Assessing construct validity in organizational research. Administrative science quarterly, 421-458.

Baumgartner, R. J. (2014). Managing corporate sustainability and CSR: A conceptual framework combining values, strategies and instruments contributing to sustainable development. Corporate Social Responsibility and Environmental Management, 21(5), 258-271.

Blome, C., Hollos, D., \& Paulraj, A. (2014). Green procurement and green supplier development: antecedents and effects on supplier performance. International Journal of Production Research, 52(1), 32-49.

Bogle, I. D. L. (2017). A perspective on smart process manufacturing research challenges for process systems engineers. Engineering, 3(2), 161-165.

Büyüközkan, G., \& Çifçi, G. (2012). A novel hybrid MCDM approach based on fuzzy DEMATEL, fuzzy ANP and fuzzy TOPSIS to evaluate green suppliers. Expert Systems with Applications, 39(3), 3000-3011.

Chin, T. A., Tat, H. H., \& Sulaiman, Z. (2015). Green supply chain management, environmental collaboration and sustainability performance. Procedia Cirp, 26, 695-699.

Chin, W. W., Gopal, A., \& Salisbury, W. D. (1997). Advancing the theory of adaptive structuration: The development of a scale to measure faithfulness of appropriation. Information systems research, 8(4), 342-367.

Cohen, M. J. (2020). Does the COVID-19 outbreak mark the onset of a sustainable consumption transition? : Taylor \& Francis.

Compact, G. U. G. (2017). Business Reporting on the SDGs: An Analysis of the Goals and Targets. GRI: Amsterdam, The Netherlands.

Dabhilkar, M., Bengtsson, L., \& Lakemond, N. (2016). Sustainable supply management as a purchasing capability. International Journal of Operations \& Production Management.

Dam, L., \& Petkova, B. (2014). The impact of environmental supply chain sustainability programs on shareholder wealth. International Journal of Operations \& Production Management, 34(5), 586-6o9.

Evans, A., Strezov, V., \& Evans, T. J. (2009). Assessment of sustainability indicators for renewable energy technologies. Renewable and sustainable energy reviews, 13(5), 1082-1088.

Fornell, C., \& Larcker, D. F. (1981). Evaluating structural equation models with unobservable variables and measurement error. Journal of marketing research, 18(1), 39-50.

Galankashi, M. R., Chegeni, A., Soleimanynanadegany, A., Memari, A., Anjomshoae, A., Helmi, S. A., \& Dargi, A. (2015). Prioritizing green supplier selection criteria using fuzzy analytical network process. Procedia Cirp, 26, 689-694.

Garetti, M., \& Taisch, M. (2012). Sustainable manufacturing: trends and research challenges. Production planning \& control, 23(2-3), 83-104.

Hair Jr, J. F., Sarstedt, M., Hopkins, L., \& Kuppelwieser, V. G. (2014). Partial least squares structural equation modeling (PLS-SEM). European Business Review.

Haleem, A., \& Javaid, M. (2020). Medical 4.0 and its role in healthcare during COVID-19 pandemic: A review. Journal of Industrial Integration and Management, 2030004.

Halisçelik, E., \& Soytas, M. A. (2019). Sustainable development from millennium 2015 to 


\section{Review of Economics and Development Studies, Vol. 6 (4) 2020, 941 - 954}

Sustainable Development Goals 2030. Sustainable Development, 27(4), 545-572.

Handfield, R. B., Melnyk, S. A., Calantone, R. J., \& Curkovic, S. (2001). Integrating environmental concerns into the design process: the gap between theory and practice. IEEE Transactions on engineering management, 48(2), 189-208.

Hong, J., Zhang, Y., \& Ding, M. (2018). Sustainable supply chain management practices, supply chain dynamic capabilities, and enterprise performance. Journal of cleaner production, 172, 3508-3519.

Khoshfetrat, S., Rahiminezhad Galankashi, M., \& Almasi, M. (2020). Sustainable supplier selection and order allocation: a fuzzy approach. Engineering Optimization, 52(9), 1494-1507.

Klassen, R. D., \& Vachon, S. (2003). Collaboration and evaluation in the supply chain: The impact on plant-level environmental investment. Production and operations management, 12(3), 336-352.

Kline, R. B. (2015). Principles and practice of structural equation modeling: Guilford publications.

Krause, D. R., Vachon, S., \& Klassen, R. D. (2009). Special topic forum on sustainable supply chain management: introduction and reflections on the role of purchasing management. Journal of Supply Chain Management, 45(4), 18-25.

Kumar, A., Luthra, S., Mangla, S. K., \& Kazançoğlu, Y. (2020). COVID-19 impact on sustainable production and operations management. Sustainable Operations and Computers, 1, 1-7.

Longoni, A., \& Cagliano, R. (2015). Environmental and social sustainability priorities: Their integration in operations strategies. International Journal of Operations \& Production Management, 35(2), 216-245.

Lu, H. E., Potter, A., Sanchez Rodrigues, V., \& Walker, H. (2018). Exploring sustainable supply chain management: a social network perspective. Supply Chain Management: An International Journal, 23(4), 257-277.

Machado, C. G., Winroth, M. P., \& Ribeiro da Silva, E. H. D. (2020). Sustainable manufacturing in Industry 4.0: an emerging research agenda. International Journal of Production Research, 58(5), 1462-1484.

Marshall, D., McCarthy, L., McGrath, P., \& Claudy, M. (2015). Going above and beyond: how sustainability culture and entrepreneurial orientation drive social sustainability supply chain practice adoption. Supply Chain Management: An International Journal, 20(4), 434454 .

Min, H., \& Galle, W. P. (2001). Green purchasing practices of US firms. International Journal of Operations \& Production Management.

Mitra, S., \& Datta, P. P. (2014). Adoption of green supply chain management practices and their impact on performance: an exploratory study of Indian manufacturing firms. International Journal of Production Research, 52(7), 2085-2107.

Montabon, F., Pagell, M., \& Wu, Z. (2016). Making sustainability sustainable. Journal of Supply Chain Management, 52(2), 11-27.

Mou, N., Chang, J., \& Chen, Z. (2018). Sustainable supplier selection based on Pd-HFLTS and group decision-making theory. Computer Integrated Manufacturing Systems, 24(5), 12611278.

Pagell, M., Wu, Z., \& Wasserman, M. E. (2010). Thinking differently about purchasing portfolios: an assessment of sustainable sourcing. Journal of Supply Chain Management, 46(1), 57-73.

Pajunen, N., Watkins, G., Wierink, M., \& Heiskanen, K. (2012). Drivers and barriers of effective industrial material use. Minerals Engineering, 29, 39-46.

Pakdeechoho, N., \& Sukhotu, V. (2018a). Sustainable supply chain collaboration: incentives in emerging economies. Journal of Manufacturing Technology Management, 29(2), 273-294.

Pakdeechoho, N., \& Sukhotu, V. (2018b). Sustainable supply chain collaboration: incentives in 


\section{Review of Economics and Development Studies, Vol. 6 (4) 2020, 941 - 954}

emerging economies. Journal of Manufacturing Technology Management.

Paulraj, A. (2011). Understanding the relationships between internal resources and capabilities, sustainable supply management and organizational sustainability. Journal of Supply Chain Management, 47(1), 19-37.

Peng, J.-j., Tian, C., Zhang, W.-y., Zhang, S., \& Wang, J.-q. (2020). An integrated multi-criteria decision-making framework for sustainable supplier selection under picture fuzzy environment. Technological and Economic Development of Economy, 26(3), 573-598.

Porter, M. E., \& Van der Linde, C. (1995). Toward a new conception of the environmentcompetitiveness relationship. Journal of economic perspectives, 9(4), 97-118.

Pullman, M. E., Maloni, M. J., \& Carter, C. R. (2009). Food for thought: social versus environmental sustainability practices and performance outcomes. Journal of Supply Chain Management, 45(4), 38-54.

Ramayah, T., \& Rahbar, E. (2013). Greening the environment through recycling: an empirical study. Management of Environmental Quality: An International Journal.

Rao, P., \& Holt, D. (2005). Do green supply chains lead to competitiveness and economic performance? International Journal of Operations \& Production Management.

Rehman, M. A., Seth, D., \& Shrivastava, R. (2016). Impact of green manufacturing practices on organisational performance in Indian context: an empirical study. Journal of cleaner production, 137, 427-448.

Schaltegger, S., Burritt, R., Beske, P., \& Seuring, S. (2014). Putting sustainability into supply chain management. Supply Chain Management: An International Journal.

Schmidt, C. G., Foerstl, K., \& Schaltenbrand, B. (2017). The supply chain position paradox: green practices and firm performance. Journal of Supply Chain Management, 53(1), 3-25.

Seuring, S., \& Müller, M. (2008). From a literature review to a conceptual framework for sustainable supply chain management. Journal of cleaner production, 16(15), 1699-1710.

Sezen, B., \& Cankaya, S. Y. (2013). Effects of green manufacturing and eco-innovation on sustainability performance. Procedia-Social and Behavioral Sciences, 99, 154-163.

Stark, R., Seliger, G., \& Bonvoisin, J. (2017). Sustainable manufacturing: Challenges, solutions and implementation perspectives: Springer Nature.

Tate, W. L., Ellram, L. M., \& Dooley, K. J. (2012). Environmental purchasing and supplier management (EPSM): Theory and practice. Journal of Purchasing and Supply Management, 18(3), 173-188.

Vachon, S., \& Klassen, R. D. (2006). Extending green practices across the supply chain: the impact of upstream and downstream integration. International Journal of Operations \& Production Management, 26(7), 795-821.

Veleva, V., \& Ellenbecker, M. (2001). Indicators of sustainable production: framework and methodology. Journal of cleaner production, 9(6), 519-549.

Yoshikawa, H. (2008). Synthesiology as sustainability science. Sustainability Science, 3(2), 169.

Zailani, S. H. M., Eltayeb, T. K., Hsu, C. C., \& Tan, K. C. (2012). The impact of external institutional drivers and internal strategy on environmental performance. International Journal of Operations \& Production Management.

Zhu, Q., \& Geng, Y. (2001). Integrating environmental issues into supplier selection and management. Greener Management International, 35(35), 27-40.

Zhu, Q., \& Sarkis, J. (2004). Relationships between operational practices and performance among early adopters of green supply chain management practices in Chinese manufacturing enterprises. Journal of Operations Management, 22(3), 265-289. 
Annexure - A. Profile of the responding companies

\begin{tabular}{|c|c|c|}
\hline Characteristics of respondents (sample size, $n=295$ ) & Frequency & $\%$ \\
\hline \multicolumn{3}{|l|}{ Number of employees } \\
\hline Less than 200 & 157 & $53 \%$ \\
\hline Equal to or more than 200 & 138 & $47 \%$ \\
\hline \multicolumn{3}{|l|}{ Annual sales volume } \\
\hline Less than $\$ 10$ million & 116 & $39 \%$ \\
\hline$\$ 10-\$ 49$ million & 93 & $32 \%$ \\
\hline$\$ 50-\$ 99$ million & 38 & $13 \%$ \\
\hline \$100-\$499 million & 41 & $14 \%$ \\
\hline Equal to or more than $\$ 500$ million & 7 & $2 \%$ \\
\hline \multicolumn{3}{|l|}{ Type of industry (ISIC code) } \\
\hline $\begin{array}{l}\text { Production, processing and preserving of meat and meat products } \\
\text { (classification code: } 404010100 \text { ) }\end{array}$ & 20 & $7 \%$ \\
\hline $\begin{array}{l}\text { Processing and preserving of fish and fish products (classification code: } \\
404010200 \text { ) }\end{array}$ & 21 & $7 \%$ \\
\hline $\begin{array}{l}\text { Processing and preserving of fruit and vegetables (jam, jellies, fruit) } \\
\text { (classification code: } 404010300 \text { ) }\end{array}$ & 30 & $10 \%$ \\
\hline Manufacture of edible oil and ghee (classification code: 404010400 ) & 19 & $6 \%$ \\
\hline Manufacture of dairy products (classification code: 404010500) & 7 & $2 \%$ \\
\hline Manufacture of grain mills products (classification code: 404010600) & 34 & $12 \%$ \\
\hline $\begin{array}{l}\text { a. Rice Processing (husking, semi-wholly milled etc.) (classification code: } \\
\text { 404010610) }\end{array}$ & 14 & $5 \%$ \\
\hline $\begin{array}{l}\text { b. Manufacture of other grain mills products (classification code: } \\
404010620 \text { ) }\end{array}$ & 24 & $8 \%$ \\
\hline $\begin{array}{l}\text { Manufacture of starches and starch products (classification code: } \\
404010700 \text { ) }\end{array}$ & 7 & $2 \%$ \\
\hline Manufacture of other food products (classification code: 404010100) & 14 & $5 \%$ \\
\hline Manufacture of feeding stuff for animals (classification code: 404010800) & 20 & $7 \%$ \\
\hline $\begin{array}{l}\text { Processing/blending of spices, tea, coffee etc. and manufacturing } \\
\text { (classification code: } 404010900 \text { ) }\end{array}$ & 13 & $4 \%$ \\
\hline Manufacture of sugar (classification code: 404011000 ) & 24 & $8 \%$ \\
\hline $\begin{array}{l}\text { Manufacture of bakery other food products n.e.c. (classification code: } \\
404011100 \text { ) }\end{array}$ & 25 & $8 \%$ \\
\hline Manufacture of beverages (classification code: 404011200 ) & 5 & $2 \%$ \\
\hline a. Production of mineral and drinking water (classification code: 404011210 ) & 13 & $4 \%$ \\
\hline $\begin{array}{l}\text { b. Manufacture of soft drinks and other beverages (classification code: } \\
404011220 \text { ) }\end{array}$ & 5 & $2 \%$ \\
\hline \multicolumn{3}{|l|}{ Target market } \\
\hline Domestic & 138 & $47 \%$ \\
\hline Overseas & 39 & $13 \%$ \\
\hline Both & 118 & $40 \%$ \\
\hline
\end{tabular}

